\title{
Effects on prolactin secretion and binding to dopaminergic receptors in sleep-deprived lupus-prone mice
}

\author{
B.D. Palma, D.C. Hipolide and S. Tufik \\ Departamento de Psicobiologia, Universidade Federal de São Paulo, São Paulo, SP, Brasil \\ Correspondence to: B.D. Palma, Departamento de Psicobiologia, UNIFESP, Rua Napoleão de Barros, \\ 925, 04024-002 São Paulo, SP, Brasil \\ Fax: +55-11-5572-5092. E-mail: biapalma@uol.com.br
}

\begin{abstract}
Sleep disturbances have far-reaching effects on the neuroendocrine and immune systems and may be linked to disease manifestation. Sleep deprivation can accelerate the onset of lupus in NZB/NZWF ${ }_{1}$ mice, an animal model of severe systemic lupus erythematosus. High prolactin (PRL) concentrations are involved in the pathogenesis of systemic lupus erythematosus in human beings, as well as in NZB/NZWF ${ }_{1}$ mice. We hypothesized that PRL could be involved in the earlier onset of the disease in sleep-deprived NZB/NZWF ${ }_{1}$ mice. We also investigated its binding to dopaminergic receptors, since PRL secretion is mainly controlled by dopamine. Female NZB/NZWF 1 mice aged 9 weeks were deprived of sleep using the multiple platform method. Blood samples were taken for the determination of $\mathrm{PRL}$ concentrations and quantitative receptor autoradiography was used to map binding of the tritiated dopaminergic receptor ligands $\left[{ }^{3} \mathrm{H}\right]-\mathrm{SCH} 23390,\left[{ }^{3} \mathrm{H}\right]$-raclopride and $\left[{ }^{3} \mathrm{H}\right]-\mathrm{WIN} 35,428$ to $\mathrm{D}_{1}$ and $\mathrm{D}_{2}$ dopaminergic receptors and dopamine transporter sites throughout the brain, respectively. Sleep deprivation induced a significant decrease in plasma PRL secretion $(2.58 \pm 0.95 \mathrm{ng} / \mathrm{mL})$ compared with the control group $(25.25 \pm 9.18 \mathrm{ng} / \mathrm{mL})$. The binding to $D_{1}$ and $D_{2}$ binding sites was not significantly affected by sleep deprivation; however, dopamine transporter binding was significantly increased in subdivisions of the caudate-putamen - posterior (16.52 \pm 0.5 vs $14.44 \pm 0.6$ ), dorsolateral (18.84 \pm 0.7 vs $15.97 \pm 0.7)$ and ventrolateral $(24.99 \pm 0.5$ vs $22.54 \pm 0.7 \mu \mathrm{Ci} / \mathrm{g})$, in the sleep-deprived mice when compared to the control group. These results suggest that PRL is not the main mechanism involved in the earlier onset of the disease observed in sleepdeprived NZB/NZWF 1 mice and the reduction of $\mathrm{PRL}$ concentrations after sleep deprivation may be mediated by modifications in the dopamine transporter sites of the caudate-putamen.
\end{abstract}

Key words: Systemic lupus erythematosus; NZB/NZWF 1 mice; Prolactin; Stress; Autoradiography; Dopamine transporter

Presented at the XI Congresso Brasileiro do Sono, Fortaleza, CE, Brazil, November 11-14, 2007.

Research supported by FAPESP-CEPID (\#01/07263-0, \#98/14303-3) and AFIP.

Received December 27, 2007. Accepted January 26, 2009

\section{Introduction}

Systemic lupus erythematosus (SLE) is a prototype autoimmune rheumatic disease, which presents many immunological abnormalities, such as B cell hyperactivity, antinuclear antibodies (ANA), and immune complex deposition that can lead to arthritis, skin rash, and glomerulonephritis. The strongest risk factor for the development of SLE is gender, since it tends to develop or is exacerbated during pregnancy and the postpartum period (1). The autoimmune-prone NZB/NZWF ${ }_{1}$ mouse is an excellent model for SLE. Like humans with SLE, these mice display a pathognomonic ANA response that includes anti-doublestranded DNA, and they spontaneously develop fatal glomerulonephritis. Also, similar to humans, the disease is most frequent in female mice (2).

Accumulating evidence suggests that prolactin (PRL) is involved in the pathogenesis of SLE. PRL plays a significant role in the regulation of the humoral and cellular immune responses in physiological as well as pathological states, 
such as autoimmune diseases (3). Increased serum PRL levels have been reported in lupus patients of both genders, and have been associated with accelerated disease expression in lupus-prone mice $(4,5)$. The primary signal for $\mathrm{PRL}$ secretion is under tonic inhibitory control by hypothalamic dopamine (for a review, see Ref. 6). Since elevated secretion of PRL is common in SLE, we hypothesized that this endocrine imbalance is a consequence of impaired dopaminergic regulation in the central nervous system. The results of some studies are consistent with the hypothesis that lupus-like disease compromises dopaminergic neurotransmission in the central nervous system $(7,8)$.

SLE patients display a variety of neurologic manifestations, which may include sleep disturbances (9). According to Valencia-Flores and colleagues (10), these patients are sleepier during the day by virtue of sleep fragmentation, with more arousals and sleep stage transitions. In addition, the disease is exacerbated by sleep disruption. Recent data from our laboratory indicated that the NZB/ $\mathrm{NZWF}_{1}$ mice subjected to sleep deprivation (SD) show an earlier onset of the disease reflected by increased numbers of ANA (11). There is evidence to support the view that sleep disturbances lead to hormonal, neurochemical and immunological alterations that may be linked to disease manifestation (12-16). For instance, we recently demonstrated that there was an increase in circulating levels of corticosterone in NZB/NZWF ${ }_{1}$ animals as the disease progressed, and this effect was more evident in sleep-deprived mice (17).

In view of these considerations, the aim of the present study was to examine the impact of $S D$ on the pattern of $P R L$ secretion as well as the regulation of dopaminergic receptors in multiple brain regions in $\mathrm{NZB} / \mathrm{NZWF}_{1}$ mice. We were particularly interested in the hypothesis that SD may lead to hormonal and neurochemical changes since these factors are associated with lupus onset. To this end, we employed a well-established procedure for producing SD and examined its effects on PRL secretion. This was complemented by quantitative autoradiographic analyses of $\left[{ }^{3} \mathrm{H}\right]-\mathrm{SCH} 23390$, $\left[{ }^{3} \mathrm{H}\right]$-raclopride and $\left[{ }^{3} \mathrm{H}\right]$-WIN35,428 binding in order to detect possible changes in $D_{1}$ and $D_{2}$ receptors and in dopamine transporter (DAT) sites, respectively, throughout the brain of sleep-deprived mice after SD.

\section{Material and Methods}

\section{Animals}

New Zealand black (NZB, females) and New Zealand white (NZW, males) mice were obtained from Universidade of São Paulo (São Paulo, SP) and were mated in our Research Laboratory to produce NZB/NZWF ${ }_{1}$ hybrids.
After weaning, NZB/NZWF ${ }_{1}$ mice were housed in groups of 6 in plastic cages filled with hardwood bedding, receiving water and rodent chow ad libitum. The animals were kept in a room with controlled lighting (12-h light/dark cycle) and temperature $\left(24 \pm 2^{\circ} \mathrm{C}\right)$. Due to the fact that murine lupus shows a preponderance in females, only this gender was used in the present study. All procedures were approved by the Ethics Committee of UNIFESP (CEP \#1163/01) and carried out in accordance with the rules and regulations on animal care of the National Institutes of Health (http:// www.nih.gov/).

\section{Sleep deprivation}

Female NZB/NZWF 1 mice aged 10 weeks (a period when they were considered to be healthy) were subjected to SD using the platform method. The method of SD used was an adaptation of the multiple platform method, originally developed for rats (18). The technique is based on the muscle atonia that accompanies paradoxical sleep (19). Briefly, 12 narrow circular platforms (3 cm in diameter) were placed inside a tiled tank $(41 \times 34 \times 17 \mathrm{~cm})$ filled with water to within $1 \mathrm{~cm}$ below the upper border of the platform. Groups of 6 mice were placed on the platforms in each tank, an arrangement that allowed them to move inside the tank, jumping from one platform to the other. In this procedure, the animals are aroused from sleep when the loss of muscle tone leads them to fall off the platform. This method produces a consistent amount of sleep reduction in mice (20).

Mice were randomly assigned to two groups containing 12 mice each: control mice remained in their home-cages in the SD room and sleep deprivation (SD) mice were deprived of sleep for two periods of $96 \mathrm{~h}$ each separated by an interval of three days. During the interval, mice were placed back in their home-cage. Throughout the study both groups had free access to food and water. This experimental protocol was carried out in an attempt to simulate a chronic condition of SD (similar to that which is observed in chronic inflammatory disease) (11).

\section{Effect of SD on PRL secretion in NZB/NZWF 1 mice (Experiment 1)}

Immediately after the end of SD, the animals $(\mathrm{N}=12)$ were rapidly decapitated and trunk blood was collected into tubes containing EDTA.

Hormone determination. Immediately after sampling, blood was centrifuged at $2500 \mathrm{rpm}$ at $4^{\circ} \mathrm{C}$ for $10 \mathrm{~min}$ and plasma was separated and stored at $-80^{\circ} \mathrm{C}$. Radioimmunoassay for mouse PRL was performed by the National Hormone and Peptide Program (USA). The detection limit of the assay was $1.0 \mathrm{ng} / \mathrm{mL}$ and intra-assay variation was $7 \%$. 
Assessment of $D_{1}$ and $D_{2}$ receptors and DAT binding

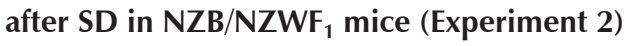

Immediately after the end of SD and decapitation of the animals in Experiment 1, the brain was rapidly removed, frozen over dry ice, and stored at $-80^{\circ} \mathrm{C}$.

Autoradiography procedures. Coronal cryostat sections $(20 \mu \mathrm{m})$ were cut at $-18^{\circ} \mathrm{C}$ from the olfactory bulbs to the substantia nigra, mounted onto lysine-coated slides and then stored at $-80^{\circ} \mathrm{C}$. Binding assays for $D_{1}$ and $D_{2}$ receptors and DAT followed the procedures of Nobrega et al. (21) and Wilson et al. (22). Briefly, to remove the endogenous ligands, the slide-mounted sections were pre-incubated at room temperature in $50 \mathrm{mM}$ Tris buffer, $\mathrm{pH} 7.4$, for 30 min for $D_{1}$ binding; in $50 \mathrm{mM}$ Tris buffer, $\mathrm{pH} 7.4$, for 15 min for $\mathrm{D}_{2}$ binding, and in $25 \mathrm{mM}$ Tris buffer, $\mathrm{pH}$ 7.7, for $20 \mathrm{~min}$ for DAT. To label $D_{1}$ sites, sections were incubated with $2 \mathrm{nM}\left[{ }^{3} \mathrm{H}\right]-$ $\mathrm{SCH} 23390$ (Perkin Elmer, USA; $85 \mathrm{Ci} / \mathrm{mmol}$ ) for $90 \mathrm{~min}$ at $37^{\circ} \mathrm{C}$. For $D_{2}$ receptors, the sections were incubated with 2 $\mathrm{nM}\left[{ }^{3} \mathrm{H}\right]$-raclopride (Perkin Elmer; $87 \mathrm{Ci} / \mathrm{mmol}$ ) for $120 \mathrm{~min}$ at room temperature. For DAT sites, the sections were incubated with [ $\left.{ }^{3} \mathrm{H}\right]-$ WIN35,428 (Perkin Elmer; $85.6 \mathrm{Ci} / \mathrm{mmol}$ ) for $120 \mathrm{~min}$ at room temperature.

Non-specific binding was defined as binding in the presence of $2 \mu \mathrm{M}$ butaclamol (Sigma, USA), $10 \mu \mathrm{M}$ sulpiride (Sigma) or $30 \mu \mathrm{M}$ cocaine (Sigma), for $\mathrm{D}_{1}, \mathrm{D}_{2}$ and DAT sites, respectively. Slides were then rinsed in cold buffer, followed by cold distilled water, then air-dried and exposed to Kodak Biomax (Scientific Imaging Film) for 4 weeks for $\left[{ }^{3} \mathrm{H}\right]-\mathrm{SCH} 23390$ and $\left[{ }^{3} \mathrm{H}\right]-W I N 35,428$, or 5 weeks for $\left[{ }^{3} \mathrm{H}\right]-$ raclopride in the presence of calibrated standards. Densitometric analyses were performed using an M2 MCID system (Imaging Research, Canada) on coded films. Anatomical regions were defined according to the atlas of Franklin and Paxinos (23) and analyzed without knowledge of the group membership of the animals.

\section{Statistical analysis}

In both experiments, data were analyzed by the Student $t$-test. Data are reported as means \pm SEM. A P value $\leq 0.05$ was considered to be statistically significant.

\section{Results}

Effect of SD on plasma PRL secretion in $N Z B / N Z W F_{1}$ mice

Figure 1 shows that $P R L$ concentrations were ten times lower $(2.58 \mathrm{ng} / \mathrm{mL})$ in sleep-deprived mice compared to control mice $(25.25 \mathrm{ng} / \mathrm{mL}$; $\mathrm{P}<0.02)$.

Assessments of $D_{1}$ and $D_{2}$ receptors and DAT binding after SD in NZB/NZWF mice $_{1}$

$\left[{ }^{3} \mathrm{H}\right]-\mathrm{SCH} 23390$ and $\left[{ }^{3} \mathrm{H}\right]$-raclopride binding to $D_{1}$ and
$D_{2}$ receptors. Binding to $D_{1}$ and $D_{2}$ receptors did not differ statistically among sleep-deprived mice and the control group in any of the brain regions analyzed (Tables 1 and 2).

[ $\left.{ }^{3} \mathrm{H}\right]$-WIN35,428 binding to DAT sites. As shown in Table 3, [ $\left.{ }^{3} \mathrm{H}\right]-$ WIN35,428 binding was significantly increased in three subdivisions of the caudate-putamen in the sleepdeprived mice when compared to the control group. Figure 2 illustrates increased binding in three subdivisions of the caudate-putamen (posterior, dorsolateral and ventrolateral).

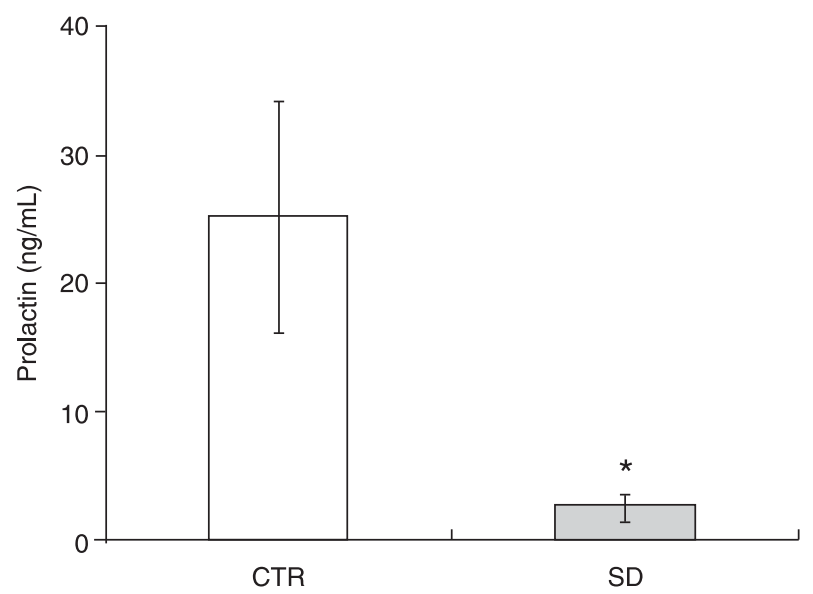

Figure 1. Plasma prolactin concentrations in sleep-deprived (SD) and control (CTR) NZB/NZWF 1 mice. Data are reported as means \pm SEM. ${ }^{*} \mathrm{P}<0.02$ compared to control (Student $t$-test).

Table 1. Sleep deprivation has no effect on $\left[{ }^{3} \mathrm{H}\right]-\mathrm{SCH} 23390$ binding to D1 receptors.

\begin{tabular}{lrr}
\hline & $\begin{array}{c}\text { Control } \\
(\mathrm{N}=8)\end{array}$ & $\begin{array}{c}\text { Sleep } \\
\text { deprivation } \\
(\mathrm{N}=10)\end{array}$ \\
\hline Caudate putamen & & \\
$\quad$ Anterior & $29.58 \pm 0.98$ & $29.41 \pm 0.65$ \\
Posterior & $24.30 \pm 0.48$ & $22.37 \pm 0.74$ \\
Dorsomedial & $26.42 \pm 1.02$ & $26.70 \pm 0.79$ \\
Dorsolateral & $26.92 \pm 0.94$ & $27.40 \pm 0.71$ \\
Ventrolateral & $28.49 \pm 1.11$ & $29.32 \pm 0.80$ \\
Nucleus accumbens & $23.72 \pm 1.05$ & $25.61 \pm 0.49$ \\
Core & $26.57 \pm 0.92$ & $27.53 \pm 0.62$ \\
$\quad$ Shell & $22.77 \pm 1.12$ & $23.54 \pm 0.69$ \\
Olfactory tubercle & $26.52 \pm 1.09$ & $28.78 \pm 0.77$ \\
Substantia nigra & $15.16 \pm 0.56$ & $15.58 \pm 0.39$ \\
$\quad$ Reticular part & $15.80 \pm 0.68$ & $16.50 \pm 0.35$ \\
Compact part & $13.00 \pm 0.40$ & $13.26 \pm 0.43$ \\
Lateral part & $6.82 \pm 0.32$ & $8.00 \pm 0.65$ \\
Ventral tegmental area & $2.47 \pm 0.25$ & $2.71 \pm 0.15$ \\
Nucleus of the ansa lenticularis & $9.44 \pm 0.27$ & $8.77 \pm 0.32$ \\
Globus pallidus & $3.20 \pm 0.17$ & $2.86 \pm 0.17$ \\
Amygdala & $12.10 \pm 0.32$ & $12.55 \pm 0.58$
\end{tabular}

Data are reported as means \pm SEM (pmol/g tissue). There were no statistical differences between sleep-deprived and control mice (Student $t$-test). 
Table 2. Sleep deprivation has no effect on $\left[{ }^{3} \mathrm{H}\right]$-raclopride binding to $D_{2}$ receptors.

\begin{tabular}{lrr}
\hline & \multicolumn{1}{c}{$\begin{array}{c}\text { Control } \\
(\mathrm{N}=8)\end{array}$} & $\begin{array}{r}\text { Sleep deprivation } \\
(\mathrm{N}=10)\end{array}$ \\
\hline Caudate putamen & & \\
$\quad$ Anterior & $8.30 \pm 0.15$ & $8.79 \pm 0.27$ \\
$\quad$ Posterior & $9.46 \pm 0.19$ & $9.32 \pm 0.22$ \\
$\quad$ Dorsomedial & $8.52 \pm 0.19$ & $8.46 \pm 0.26$ \\
$\quad$ Dorsolateral & $11.53 \pm 0.19$ & $11.48 \pm 0.38$ \\
$\quad$ Ventrolateral & $11.53 \pm 0.19$ & $12.75 \pm 0.46$ \\
Nucleus accumbens & $5.57 \pm 0.19$ & $5.79 \pm 0.21$ \\
$\quad$ Core & $5.68 \pm 0.37$ & $6.18 \pm 0.20$ \\
$\quad$ Shell & $5.21 \pm 0.32$ & $5.34 \pm 0.30$ \\
Olfactory tubercle & $6.14 \pm 0.16$ & $6.25 \pm 0.16$ \\
Substantia nigra & $3.41 \pm 0.12$ & $3.13 \pm 0.17$ \\
\hline
\end{tabular}

Data are reported as means \pm SEM (pmol/g tissue). There were no statistical differences between sleep-deprived and control mice (Student $t$-test).
Table 3. $\left[{ }^{3} \mathrm{H}\right]-$ WIN35,428 binding to dopamine transporter.

\begin{tabular}{lrr}
\hline & $\begin{array}{c}\text { Control } \\
(\mathrm{N}=8)\end{array}$ & $\begin{array}{c}\text { Sleep deprivation } \\
(\mathrm{N}=10)\end{array}$ \\
\hline Caudate putamen & & \\
$\quad$ Anterior & $15.05 \pm 0.53$ & $16.12 \pm 0.69$ \\
$\quad$ Posterior & $14.44 \pm 0.65$ & $16.52 \pm 0.51^{*}$ \\
$\quad$ Dorsomedial & $15.84 \pm 0.88$ & $16.40 \pm 0.67$ \\
$\quad$ Dorsolateral & $15.97 \pm 0.72$ & $18.84 \pm 0.73^{*}$ \\
$\quad$ Ventrolateral & $22.54 \pm 0.71$ & $24.99 \pm 0.54^{*}$ \\
Nucleus accumbens & & \\
$\quad$ Core & $14.68 \pm 0.60$ & $15.15 \pm 0.67$ \\
$\quad$ Shell & $7.25 \pm 0.26$ & $7.30 \pm 0.29$ \\
Olfactory tubercle & $12.36 \pm 0.48$ & $13.06 \pm 0.39$ \\
Substantia nigra & & \\
$\quad$ Compact part & $7.90 \pm 0.30$ & $7.69 \pm 0.40$ \\
$\quad$ Reticular part & $3.09 \pm 0.15$ & $2.76 \pm 0.14$ \\
Ventral tegmental area & $7.95 \pm 0.09$ & $7.92 \pm 0.41$ \\
\hline
\end{tabular}

Data are reported as means \pm SEM (pmol/g tissue). ${ }^{*} \mathrm{P}<0.05$ compared to control (Student $t$-test).
Figure 2. Illustration of increased dopamine transporter binding in the caudateputamen nucleus after sleep deprivation. $A$, Control; $B$, sleep deprivation. CPu Post = posterior caudate-putamen; $\mathrm{CPu} \mathrm{DL}=$ dorsolateral caudate-putamen; $\mathrm{CPu} \mathrm{VL}=$ ventrolateral caudate-putamen.
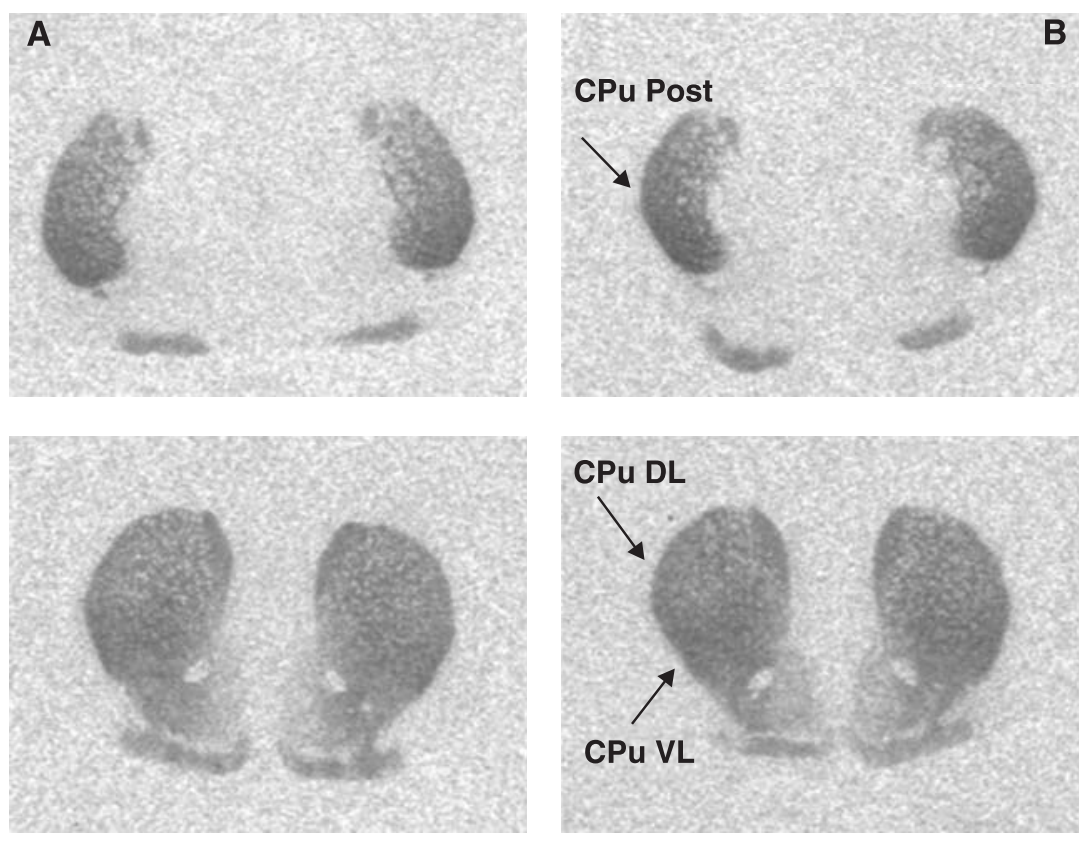

\section{Discussion}

There is increasing evidence that $P R L$ can exacerbate SLE, particularly, in experimental models (5). Previous data from our laboratory indicated that the NZB/NZWF mice subjected to SD had an earlier onset of the disease as reflected by an increased number of ANA (11). In the present study, we had hypothesized that the SD could increase PRL secretion, and this would be involved in an earlier onset of the disease. However, we observed a significant reduction in plasma PRL concentrations in sleepdeprived mice.

To our knowledge, the present study provides the first quantification of $\mathrm{PRL}$ in NZB/NZWF${ }_{1}$ mice subjected to SD. Previous studies had already reported the effects of SD on PRL secretion. Everson and Crowley (24) reported decreased $\mathrm{PRL}$ concentrations in sleep-deprived rats, while Andersen et al. (25) found that the rats subjected to $96 \mathrm{~h}$ of $\mathrm{SD}$ had higher PRL concentrations than controls. Factors that may contribute to these inconsistencies may be the 
use of different animal species and gender or different methods and durations of SD.

There are different possible explanations for the decreased PRL secretion observed after SD in the current study. First, sleep itself is involved in PRL secretion. PRL concentrations are elevated during sleep, even if sleep is delayed (26). Moreover, short periods of SD and sleep fragmentation in humans are associated with lower nocturnal PRL levels in comparison to normal sleep (27). Second, several lines of evidence support the notion that SD is a stressful stimulus $(28,29)$. Thus, SD can be considered a type of biological stress given that sleep is essential to life and to health. It is well known that stress in a number of forms induces PRL secretion (for a review, see Ref. 6). Although PRL reliably increases in response to acute stress, $\mathrm{PRL}$ responses to chronic stress become inhibited over continuous exposure (30). The reduction in PRL in this condition is presumably due to an increase in dopamine release at the level of the median eminence (31). Our results agree with the notion that $S D$, as a type of chronic stress, leads to a reduction in PRL secretion.

Another point that needs to be considered is the fact that PRL secretion is inhibited by an increase of dopaminergic activity (for a review, see Ref. 6). Since this is the main mechanism of PRL secretion (32), we speculated whether altered dopaminergic activity could be involved. Indeed, previous SD studies have reported dopaminergic alterations, including augmented responses to dopaminergic agonists $(33,34)$ and upregulation of brain $D_{2}$ dopamine receptors (35). With respect to quantitative receptor autoradiography, we observed that $D_{1}$ and $D_{2}$ binding sites were not significantly affected by $S D$ in any brain region analyzed in NZB/NZWF ${ }_{1}$ mice. However, we observed that DAT binding was significantly increased in subdivisions of the caudate-putamen in sleep-deprived mice. The increase in DAT binding observed in the present study could reflect increased extracellular dopamine concentrations and, as such, could be related to the observed decrease of PRL levels. However, it is important to mention that the regula- tion of DAT and other neurotransmitter transporters is still not completely elucidated. A review of the literature suggests that DAT play a physiological role in the regulation of dopamine release and consequently of PRL secretion. Females lacking DAT show an impaired ability to nurse their young (36). Moreover, administration of DAT blockers has been shown to inhibit PRL secretion and to disrupt the estrous cycle of the rat (37).

The main regulation of $P R L$ secretion is mediated by three populations of hypothalamic neuroendocrine dopaminergic neurons (tuberoinfundibular, tuberohypophyseal and periventricular-hypophyseal) (6). However, some studies have also linked PRL function to striatal dopaminergic activity. Thus, Malven (37) demonstrated an inhibition of $\mathrm{PRL}$ release in conscious sheep following stimulation of nucleus accumbens and caudate-putamen. Also, consistent with this framework is a finding by Harlan et al. (38) that immunoreactive PRL cells are localized in many regions of the rat brain, including the caudate-putamen. In a recent study, Pi et al. (39) detected the expression of the long form of $P R L$ receptor $m R N A$ in the caudate-putamen. It is thus conceivable that the augmented DAT binding in the caudate-putamen observed in our study could be involved in the reduction of PRL secretion after SD.

In summary, the present results add further evidence that SD induces physiological alterations. Our data suggest that $P R L$ is not involved in the early onset of disease in sleep-deprived NZB/NZWF ${ }_{1}$ mice, and the observed reduction in $P R L$ levels after $S D$ may be mediated by modifications of the DAT sites in the caudate-putamen.

\section{Acknowledgments}

We are grateful to Karin Di Monteiro Moreira and Diva Lima for expert technical assistance and Tomé Pimentel dos Anjos for animal care. The authors would like to thank Dr. Jose Nobrega (Neuroimaging Research Section, Centre for Addiction and Mental Health, Toronto, Canada) for critically reading the manuscript and for useful comments.

\section{References}

1. Ostensen M. Sex hormones and pregnancy in rheumatoid arthritis and systemic lupus erythematosus. Ann N Y Acad Sci 1999; 876: 131-143.

2. Theofilopoulos AN, Dixon FJ. Murine models of systemic lupus erythematosus. Adv Immunol 1985; 37: 269-390.

3. Neidhart M. Prolactin in autoimmune diseases. Proc Soc Exp Biol Med 1998; 217: 408-419.

4. Jara LJ, Vera-Lastra O, Miranda JM, Alcala M, Alvarez-

Nemegyei J. Prolactin in human systemic lupus erythematosus. Lupus 2001; 10: 748-756.

5. McMurray RW. Prolactin in murine systemic lupus erythematosus. Lupus 2001; 10: 742-747.

6. Freeman ME, Kanyicska B, Lerant A, Nagy G. Prolactin: structure, function, and regulation of secretion. Physiol Rev 2000; 80: 1523-1631.

7. Anderson KK, Ballok DA, Prasad N, Szechtman H, Sakic B. 
Impaired response to amphetamine and neuronal degeneration in the nucleus accumbens of autoimmune MRL-Ipr mice. Behav Brain Res 2006; 166: 32-38.

8. Sakic B, Lacosta S, Denburg JA, Szechtman H. Altered neurotransmission in brains of autoimmune mice: pharmacological and neurochemical evidence. J Neuroimmunol 2002; 129: 84-96.

9. Sweet JJ, Doninger NA, Zee PC, Wagner LI. Factors influencing cognitive function, sleep, and quality of life in individuals with systemic lupus erythematosus: a review of the literature. Clin Neuropsychol 2004; 18: 132-147.

10. Valencia-Flores M, Resendiz M, Castano VA, Santiago V, Campos RM, Sandino S, et al. Objective and subjective sleep disturbances in patients with systemic lupus erythematosus. Arthritis Rheum 1999; 42: 2189-2193.

11. Palma BD, Gabriel A Jr, Colugnati FA, Tufik S. Effects of sleep deprivation on the development of autoimmune disease in an experimental model of systemic lupus erythematosus. Am J Physiol Regul Integr Comp Physiol 2006; 291: R1527-R1532.

12. Patchev V, Felszeghy K, Koranyi L. Neuroendocrine and neurochemical consequences of long-term sleep deprivation in rats: similarities to some features of depression. Homeost Health Dis 1991; 33: 97-108.

13. Irwin M, Thompson J, Miller C, Gillin JC, Ziegler M. Effects of sleep and sleep deprivation on catecholamine and interleukin-2 levels in humans: clinical implications. J Clin Endocrinol Metab 1999; 84: 1979-1985.

14. Spiegel K, Leproult R, Van Cauter E. Impact of sleep debt on metabolic and endocrine function. Lancet 1999; 354: 1435-1439.

15. Irie M, Nagata S, Endo Y, Kobayashi F. Effect of rapid eye movement sleep deprivation on allergen-induced airway responses in a rat model of asthma. Int Arch Allergy Immunol 2003; 130: 300-306.

16. Irwin MR, Wang M, Campomayor CO, Collado-Hidalgo A, Cole S. Sleep deprivation and activation of morning levels of cellular and genomic markers of inflammation. Arch Intern Med 2006; 166: 1756-1762.

17. Palma BD, Suchecki D, Catallani B, Tufik S. Effect of sleep deprivation on the corticosterone secretion in an experimental model of autoimmune disease. Neuroimmunomodulation 2007; 14: 72-77.

18. Suchecki $D$, Tufik $S$. Social stability attenuates the stress in the modified multiple platform method for paradoxical sleep deprivation in the rat. Physiol Behav 2000; 68: 309-316.

19. Jouvet $D$, Vimont $P$, Delorme $F$, Jouvet M. Study of selective deprivation of the paradoxal sleep phase in the cat. $C R$ Seances Soc Biol Fil 1964; 158: 756-759.

20. Silva RH, Abilio VC, Takatsu AL, Kameda SR, Grassl C, Chehin $A B$, et al. Role of hippocampal oxidative stress in memory deficits induced by sleep deprivation in mice. Neuropharmacology 2004; 46: 895-903.

21. Nobrega JN, Richter A, Tozman N, Jiwa D, Loscher W. Quantitative autoradiography reveals regionally selective changes in dopamine D1 and D2 receptor binding in the genetically dystonic hamster. Neuroscience 1996; 71: 927937.

22. Wilson JM, Nobrega JN, Carroll ME, Niznik HB, Shannak K, Lac ST, et al. Heterogeneous subregional binding patterns of $3 \mathrm{H}$-WIN 35,428 and $3 \mathrm{H}$-GBR 12,935 are differentially regulated by chronic cocaine self-administration. $J$ Neurosci 1994; 14: 2966-2979.

23. Franklin KB, Paxinos G. The mouse brain in stereotaxic coordinates. San Diego: Academic Press; 1997.

24. Everson CA, Crowley WR. Reductions in circulating anabolic hormones induced by sustained sleep deprivation in rats. Am J Physiol Endocrinol Metab 2004; 286: E1060E1070.

25. Andersen ML, Martins PJ, D'Almeida V, Bignotto M, Tufik S. Endocrinological and catecholaminergic alterations during sleep deprivation and recovery in male rats. J Sleep Res 2005; 14: 83-90.

26. Van Cauter E, Spiegel K. Hormones and metabolism during sleep. In: WJ Schwartz (Editor), Sleep science: integrating basic research and clinical practice. Basel: Karger; 1997. p 144-174.

27. Sgoifo A, Buwalda B, Roos M, Costoli T, Merati G, Meerlo $P$. Effects of sleep deprivation on cardiac autonomic and pituitary-adrenocortical stress reactivity in rats. Psychoneuroendocrinology 2006; 31: 197-208.

28. Suchecki D, Lobo LL, Hipolide DC, Tufik S. Increased ACTH and corticosterone secretion induced by different methods of paradoxical sleep deprivation. J Sleep Res 1998; 7: 276-281.

29. Perello M, Chacon F, Cardinali DP, Esquifino Al, Spinedi E. Effect of social isolation on 24-h pattern of stress hormones and leptin in rats. Life Sci 2006; 78: 1857-1862.

30. Gala RR. The physiology and mechanisms of the stressinduced changes in prolactin secretion in the rat. Life Sci 1990; 46: 1407-1420.

31. Ben-Jonathan N. Dopamine: a prolactin-inhibiting hormone. Endocr Rev 1985; 6: 564-589.

32. Asakura W, Matsumoto K, Ohta H, Watanabe H. REM sleep deprivation decreases apomorphine-induced stimulation of locomotor activity but not stereotyped behavior in mice. Gen Pharmacol 1992; 23: 337-341.

33. Tufik S, Troncone LR, Braz S, Silva-Filho AR, Neumann BG. Does REM sleep deprivation induce subsensitivity of presynaptic dopamine or postsynaptic acetylcholine receptors in the rat brain? Eur J Pharmacol 1987; 140: 215-219.

34. Nunes Junior GP, Tufik S, Nobrega JN. Autoradiographic analysis of D1 and D2 dopaminergic receptors in rat brain after paradoxical sleep deprivation. Brain Res Bull 1994; 34 : 453-456.

35. Giros B, Jaber M, Jones SR, Wightman RM, Caron MG. Hyperlocomotion and indifference to cocaine and amphetamine in mice lacking the dopamine transporter. Nature 1996; 379: 606-612.

36. King TS, Schenken RS, Kang IS, Javors MA, Riehl RM. Cocaine disrupts estrous cyclicity and alters the reproductive neuroendocrine axis in the rat. Neuroendocrinology 1990; 51: 15-22.

37. Malven PV. Inhibition of prolactin release in conscious sheep following stimulation of nucleus accumbens and caudate nucleus. Neuroendocrinology 1979; 28: 160-168.

38. Harlan RE, Shivers BD, Fox SR, Kaplove KA, Schachter BS, Pfaff DW. Distribution and partial characterization of immunoreactive prolactin in the rat brain. Neuroendocrinology 1989; 49: 7-22.

39. Pi X, Voogt JL, Grattan DR. Detection of prolactin receptor mRNA in the corpus striatum and substantia nigra of the rat. J Neurosci Res 2002; 67: 551-558. 